\title{
Индикаторы социального неблагополучия населения: этнорегиональная специфика Калмыкии, Бурятии и Тувы*
}

\author{
Евгений А. Гунаев, Ноган В. Бадмаева
}

Калмыцкий научный центр Российской академии наук, Российская Федерация,

\author{
Екатерина С. Кованова
}

Калмыцкий государственный университет им. Б. Б. Городовикова, Российская Федерация
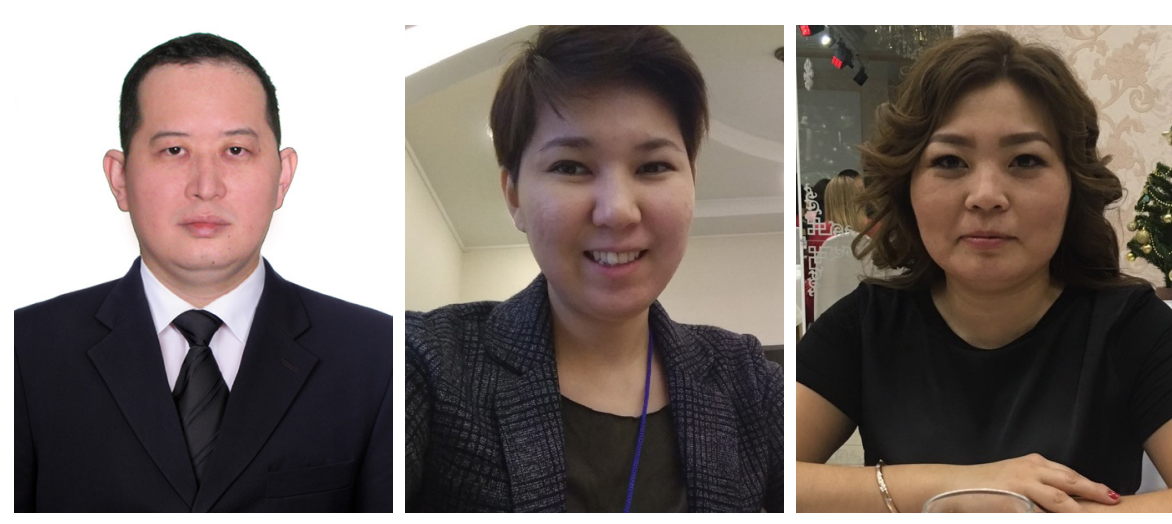

Статья посвящена проблеме социального неблагополучия в трех регионах России - Калмыкии, Бурятии и Туве, традиционно буддийских и скотоводческих. В настоящее время регионы считаются депрессивными и многие годы находятся в сложном социально-экономическом положении. В качестве инструмента анализа выбраны индикаторы социального неблагополучия: демографические, социально-экономические и индикаторы по общественной безопасности (преступности). Источниковой базой выступила официальная статистическая информация по регионам за 20172.

Население Калмыкии продолжает сокращаться, прежде всего вследствие миграционного оттока. Население Бурятии и Тувы увеличивается благодаря естественному приросту, обусловленного высокой рождаемостью. Однако положительная динамика численности осложняется высоким уровнем смертности населения трудоспособного возраста, низкими показателями ожидаемой продолжительности жизни (в Туве) и миграционным оттоком (Бурятия). Калмыкия и Тува схожи по показателям уровня безработицы и доле населения с доходами ниже прожиточного минимума в населении региона. По данным критериям обе республики относятся к числу беднейших субъектов Российской Федерации. В Бурятии относительно более лучше ситуация, однако и по данным показателям ситуация не является благоприятной.

Заключается, что проблемы Калмыкии, Бурятии и Тувы проявляется в разных показателях социального неблагополучия и соответственно требуют различных управленческих подходов их разрешении.

Ключевые слова: социальное неблагополучие; индикатор; индикатор социального неблагополучия; Калмыкия; Бурятия; Тува; экономика; демография; миграция; безработица; преступность

Статья подготовлена в рамках проекта «Социально-экономические траектории развития монголоязычных регионов России (на примере республик Калмыкия и Бурятия)» (грант РФФИ 19-010-01082).

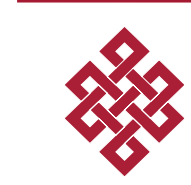

Для цитирования:

Гунаев Е. А., Бадмаева Н. В., Кованова Е. С. Индикаторы социального неблагополучия населения: этнорегиональная специфика Калмыкии, Бурятии и Тувы [Электронный ресурс] // Новые исследования Тувы. 2019, № 1. URL: https://nit.tuva.asia/nit/article/view/824 (дата обращения: дд.мм.гг.). DOI: 10.25178/ nit.2019.1.14

Гунаев Евгений Александрович - кандидат юридических наук, старший научный сотрудник отдела истории, археологии и этнологии Калмыцкого научного центра Российской академии наук. Адрес: 358000, Россия, г. Элиста, ул. Илишкина, д. 8. Тел.: +7 (84722) 3-55-06. Эл. адрес: gunaevea@kigiran.com ORCID:0000-0002-7173-4170

Бадмаева Ноган Вячеславовна - научный сотрудник отдела комплексного мониторинга и информационных технологий Калмыцкого научного центра Российской академии наук. Адрес: 358000, Россия, г. Элиста, ул. Илишкина, д. 8. Тел.: +7 (84722) 3-55-06. Эл. адрес: badmaevanv@kigiran.com ORCID:0000-0002-4799-5506

Кованова Екатерина Сергеевна - кандидат экономических наук, доцент кафедры экономической безопасности, учета и финансов Калмыцкого государственного университета им. Б. Б. Городовикова. Адрес: 358000, Россия, г. Элиста, ул. Пушкина, д. 11 . Тел.: +7 (84722) 3-82-87. Эл. адрес.: ekovanova@yandex.ru ORCID:0000-0002-4269-3795

Gunaev Yevgeniy Aleksandrovich, Candidate of Law, Senior Research Fellow, Department of History, Archaeology and Ethnology, Kalmyk Scientific Center of the Russian Academy of Sciences. Postal address: 8 Ilishkin St., Elista 358000 Russian Federation. Tel.: +7 (84722) 3-55-06 E-mail: gunaevea@kigiran.com

Badmaeva Nogan Viacheslavovna, Research Fellow, Department of Complex Monitoring and Information Technologies, Kalmyk Scientific Center of the

Russian Academy of Sciences. Postal address: 8 Ilishkin St., Elista 358000 Russian Federation. Tel.: +7 (84722) 3-55-06 E-mail: badmaevanv@kigiran.com

Kovanova Ekaterina Sergeevna, Candidate of Economics, Associate Professor, Department of Economic Security, Accounting and Finance, B. B. Gorodo-

vikov Kalmyk State University. Postal address: 11 Pushkin St., Elista 358000 Russian Federation. Tel.: +7 (84722) 3-82-87 E-mail: ekovanova@yandex.ru 


\title{
Social insecurity indicators: ethnoregional specifics in Kalmykia, Buryatia and Tuva"
}

\author{
Eugeny A. Gunaev, Nogan V. Badmaeva \\ Kalmyk Scientific Center of the Russian Academy of Sciences, Russian Federation, \\ Ekaterina S. Kovanova \\ B. B. Gorodovikov Kalmyk State University, Russian Federation
}

\begin{abstract}
The article examines indicators of social insecurity in three regions of Russia - Kalmykia, Buryatia and Tuva, where the population are majority Buddhist and involved cattle breeding. Currently, these regions are suffering from economic depression, and for many years have experienced a difficult socio-economic situation. For its sources, the article relies on the official statistics for these regions (as of 2017).

The population of Kalmykia continues to decline, primarily as a result of migration outflows, while the population of Buryatia and Tuva is increasing due to high birth rates. However, the positive dynamics of the population is complicated by the high mortality rate of the working age population, low life expectancy (in Tuva) and migration outflows (Buryatia). In terms of socio-economic indicators, Kalmykia and Tuva are similar in their levels of unemployment and the share of the population with incomes below the subsistence minimum. According to these criteria, both republics are among the poorest constituent subjects of the Russian Federation. In Buryatia, the situation is slightly better; however, its social and economic situation is still far from favorable.

We may conclude that problems of Kalmykia, Buryatia and Tuva are revealed in different indicators of social insecurity and, accordingly, require different managerial approaches to resolve them.
\end{abstract}

Keywords: social insecurity; indicators; Kalmykia; Buryatia; Tuva; economic; demography; migration; unemployment; crime

* The article was written as part of the project supported by the RFBR (Grant No. 19-010-01082, project title «Social and economic trajectories of develpoment

of Mongol-speaking regions of Russia: the case of Republics of Kalmykia and Buryatia».

\section{Для цитирования:}

Gunaev E. A., Badmaeva N. V., Kovanova E. S. Social insecurity indicators: ethnoregional specifics in Kalmykia, Buryatia and Tuva. The New Research of Tuva. 2019, № 1. URL: https://nit.tuva.asia/nit/article/ view/824 (access date: ...). DOI: 10.25178/nit.2019.1.14

\section{Введение}

Социальное неблагополучие можно определить, как «негативное состояние социума, возникающее из-за влияния различных неблагоприятных социальных и природных факторов» (Давыдов, 1995: 118). Исследователи выделяют от 3 до 200 компонентов социального неблагополучия. Изучение социального неблагополучия важно не только для страны в целом, но и для каждого региона, муниципального образования. Применительно к республикам - субъектам РФ, на территории которых проживают коренные этносы данных регионов, это имеет значение также в аспекте национальной политики государства. В особенности это важно в отношении слаборазвитых в экономическом отношении республик с малочисленным населением.

Калмыкия и Тува по объему валового регионального продукта и различным показателям социально-экономического развития регионов занимают одни из последних мест в Россий- 
ской Федерации. Более экономически развитой является Республика Бурятия в силу индустриально-аграрного типа экономики. Вместе с тем, высокая зависимость от помощи федерального центра, низкий уровень доходов, высокий уровень бедного населения, безработицы и т. д. характеризуют данные регионы, родственные по этническому (Калмыкия и Бурятия монголоязычные регионы России) и религиозному (в трех республиках исповедуют буддизм) признакам «титульных» этносов. Для всех трех регионов приоритетным направлением развития сельского хозяйства и экономики является традиционный тип хозяйствования - скотоводство. Кризисное состояние сельскохозяйственной отрасли и ее медленная модернизация в стране в целом отрицательно сказались на экономике рассматриваемых республик, что и привело к их депрессивности.

Следует отметить, что Тува только в 40-х гг. XX века вошла в состав СССР, в то время как Калмыкия и Бурятия вошли в состав России в XVII веке. Как отмечает ряд исследователей, данный переход для Тувы происходил и продолжает проходить достаточно болезненно для тувинцев, проявляясь в росте социально-негативных явлений в регионе (Дабиев, 2015: 181; Ламажаa, 2009: 124).

Цель статьи состоит в исследовании социального неблагополучия населения вышеназванных регионов при помощи специальных индикаторов. Сравнительное сопоставление позволит на примере схожих в экономическом развитии конкретных субъектов РФ выявить региональную специфику для каждого региона относительно социального неблагополучия. В данной статье мы не рассматриваем природные (экологические) факторы, ограничиваясь лишь социальными и экономическими. Кроме того, авторы не ставят целью разработать конкретную методику (формулу) оценки социального неблагополучия на уровне регионов, отдельные показатели будут рассмотрены в общем виде.

Источниковой базой исследования является статистика Росстата, опубликованная на официальном сайте в сети Интернет (http://www.gks.ru). В частности, это следующие статистические сборники с данными по субъектам Российской Федерации: «Приложение к сборнику Здравоохранение в России 2017» (статистическая информация в разрезе субъектов Российской Федерации выделена в отдельное электронное приложение, в котором опубликованы сведения о медико-демографических аспектах здоровья населения и его отдельных социально-демографических групп; информация о состоянии здравоохранения по Российской Федерации в целом и по субъектам Российской Федерации представлена в основном за 2005, 2010, 2013-2016 годы); «Регионы России. Социально-экономические показатели. 2018» (в сборнике опубликованы статистические данные о социально-экономическом положении субъектов Российской Федерации за 2005-2017 гг., в том числе по демографической ситуации в регионах России, занятости и безработице и др. Также содержится статистическая информация о состоянии преступности по субъектам Российской Федерации; по ряду показателей приведено распределение мест, занимаемых отдельными регионами в Российской Федерации); «Социально-экономические индикаторы бедности в 2013-2017 гг.» (в бюллетене представлены показатели численности и доли населения с денежными доходами ниже величины прожиточного минимума, устанавливаемого в соответствии с действующим федеральным законодательством и законодательством субъектов Российской Федерации).

Также приведены данные социологических опросов, проведенных в Калмыкии одним из соавторов данной статьи Н. В. Бадмаевой в 2015 и 2017 гг. (см.: Бадмаева, 2017, 2018).

\section{Теоретические основы и практические примеры расчетов индикаторов социального неблагополучия}

В начале 1990-х гг. в России одними из первых методику измерения социального неблагополучия предложил научно-исследовательский комитет «Теории социальных систем» Российского общества социологов Института социологии Российской академии наук (руководи- 
тель А. А. Давыдов). В основу данной методики был положен расчет того, «сколько на одного родившегося ребенка приходится смертей, разводов, безработных ,зарегистрированных преступлений, потерь из-за забастовок, т. е. негативных явлений» (Давыдов, 1995: 121). При этом поддержкой родившегося ребенка выступала покупательная способность средней заработной платы - материальное благополучие. «Чем оно выше, тем больше шансов у родившегося ребенка противостоять действию негативных явлений» (там же).

Данная методика учитывала рождение ребенка как одну из высших ценностей жизнедеятельности общества и, соответственно, снижение рождаемости как один из ведущих компонентов социального неблагополучия. Авторы методики отмечали, «что традиционно социальные показатели (заболеваемость, преступность, безработицу и т. д.) нормируют на 1 тыс. или 100 тыс. человек населения. Однако точный ежемесячный учет населения субъекта РФ затруднен из-за неконтролируемой миграции и сбора статистической информации реже, чем один раз в месяц» (Давыдов, 1995: 121). В этой связи в качестве нормирующего показателя было предложено использовать общее число родившихся, поскольку он свободен от вышеперечисленных ограничений. Умножение числа родившихся на покупательную способность средней заработной платы обусловлено тем фактом, что в относительно бедных регионах РФ может быть высокая рождаемость, обусловленная национальными традициями и рядом других устойчивых факторов. В то время как в относительно богатых субъектах РФ рождаемость может быть ниже (там же).

Для построения индекса социального неблагополучия субъектов РФ были окончательно отобраны следующие статистические показатели:

1. Число зарегистрированных умерших;

2. Число зарегистрированных разводов;

3. Число зарегистрированных родившихся;

4. Численность зарегистрированных безработных;

5. Число зарегистрированных преступлений;

6. Среднемесячная заработная плата;

7. Стоимость набора из 19 основных продуктов питания;

8. Потеря из-за забастовок (человеко-дней) (там же: 119).

Здесь следует отметить, что интерес представляет вывод О. В. Печковой, основанный на частичной критике индекса социального неблагополучия, основанного на вышеназванной методике. По ее мнению, ряд статистических показателей (численность населения, доля городского населения, розничный товарооборот, темпы роста прибыли, объем промышленного производства и др.) определяют значение индекса социального неблагополучия на $73 \%$. Данный круг статистических показателей, связанных с индексом социального неблагополучия, характеризуют степень промышленного развития региона.

Согласно данным О. В. Печковой, рассчитанным на основе метода множественной пошаговой линейной регрессии, «в 1994 г. хуже жилось в тех регионах, которые традиционно считались наиболее благополучными и являлись основой экономики страны. Напротив, дотационные, сельскохозяйственные субъекты РФ в меньшей степени пострадали в процессе экономических преобразований». Наименее социально благополучными оказались наиболее промышленно развитые регионы (с развитыми добывающими отраслями и тяжелой промышленностью), а именно Челябинская, Свердловская, Кемеровская и Пермская области и Республика Коми. А на противоположном полюсе социального благополучия оказались Алтай, Тува, Калмыкия, Карачаево-Черкесия и Адыгея (с развитым отгонно-пастбищным животноводством) (Печкова 1996: 195).

Т. М. Тихомирова и А. Г. Сукиасян предлагают применять следующие индикаторы социального неблагополучия, рассчитанные применительно к индексу развития человеческого потенциала (ИРЧП): 
- распространенность ВИЧ среди населения в возрасте 15-49 лет (на 100 тыс. чел. в возрасте 15-49 лет);

- заболеваемость туберкулезом (впервые зарегистрированные случаи и рецидивы на 100 тыс. чел.);

- смертность по причинам, связанным с алкоголизмом (на 100 тыс. чел.);

- материнская смертность (на 100 тыс. живорожденных);

- младенческая смертность (смертность детей до 5 лет в расчете на 100 тыс. рожденных живыми);

- умышленные убийства (на 100 тыс. чел.);

- самоубийства (на 100 тыс. чел.);

- общая смертность (на 100 тыс. чел.);

- уровень безработицы (на 100 тыс. чел. в возрасте 15-72 года);

- коэффициент Джини (Тихомирова, Сукиасян, 2018: 66).

Согласно выводам указанных авторов, наиболее высокие значения большинства индикаторов социального неблагополучия наблюдаются в Чукотском автономном округе и Республике Тыва.

«В Республике Тыва наиболее высокие уровни индикаторов социального неблагополучия были отмечены по умышленным убийствам, заболеваемости туберкулезом, безработице, младенческой смертности. Вместе с тем в Республике был зафиксирован один из самых низких по регионам страны уровень распространенности ВИЧ, и относительно низкое значение коэффициента Джини» (там же: 71).

В соответствии с распределением регионов России по усредненным за период 2000-2015 гг. индикаторам социального неблагополучия Республика Калмыкия была отнесена к первой группе регионов с условно благоприятными показателями. В ней уровни большинства из индикаторов социального неблагополучия существенно ниже средних по России значений (там же: 72).

Республика Бурятия была отнесена к третьей группе, куда вошли регионы с наиболее высокими значениями индикаторов социального неблагополучия. В среднем по этой группе значительно превышены общероссийские уровни всех индикаторов социального неблагополучия (там же: 73).

Республика Тыва была отнесена к нетипичным регионам по структуре индикаторов социального неблагополучия, что обусловлено значительными превышениями уровней индикаторов социального неблагополучия своих общероссийских аналогов (там же: 74).

Д. Ф. Дабиев предлагает использовать ИРЧП с учетом корректировки на индекс преступности (ИРЧПск), который характеризуют показатели убийств и покушений на убийство и умышленное причинение тяжкого вреда (на 100 тыс. населения) (Дабиев, 2015: 177). По его мнению, в Туве показатель ИРЧПск значительно ниже, чем ИРЧП. Это связано с высокой долей негативных социальных факторов в регионе (там же: 181).

Итоговым показателем, характеризующим безопасность в регионах, является уровень преступности. Коэффициент (уровень) преступности - это количество зарегистрированных преступлений на 100 тыс. чел. населения региона, которое достигло возраста уголовной ответственности. Как полагают Ю. Ю. Мартынова и С. В. Блинова, число зарегистрированных преступлений на 100 тыс. чел. населения наиболее тесно связана с такими показателями, как: задолженность по кредитам, предоставленными кредитными организациями физическим лицам руб./ чел.; величина прожиточного минимума в среднем на душу населения; заболеваемость населения активным туберкулезом на 100 тыс. чел. населения; продажа алкогольных напитков на душу населения; среднемесячная номинальная начисленная заработная плата работников организаций (Мартынова, Блинова, 2016: 108). 
Как отмечает С. В. Кандрычын, анализ в распределении группы показателей по 81 региону - субъекту РФ (за исключением столичных городов) «выявил существование значимой положительной корреляции в распределении ранговой позиции показателя смертности от внешних причин с уровнем заболеваемости туберкулезом, с уровнем заболеваемости сифилисом, с уровнем заболеваемости алкоголизмом и алкогольными психозами, с региональным показателем абортов, с процентом рожденных вне брака, с уровнем преступности и уровнем самоубийств. При этом не регистрировалась какая-либо значимая зависимость с показателем впервые выявленной наркомании, с региональным уровнем безработицы и показателем экономического благосостояния населения (использован показатель отношения денежных доходов населения к стоимости фиксированного набора товаров)» (Кандрычын, 2017: 86).

Подтверждением такого мнения служат результаты анализа региональных социоэкономических показателей, которые указывают на то, что причины социокультурного и духовного неблагополучия населения регионов, как и уровень насильственной смертности, напрямую не связаны с экономическим благосостоянием. Наиболее показательным тут является сравнение с Северо-Кавказским регионом (Кандрычын, 2017: 85; см. также: Дабиев, 2015: 181).

\section{Индикаторы социильного неблагополучия: основные группы}

Однако, на наш взгляд, полностью исключать социально-экономические показатели из индикаторов социального неблагополучия не представляется возможным. По нашему мнению, практически все индикаторы можно сгруппировать в три большие группы:

1. Демографический - увеличение или уменьшение численности населения региона. Данный показатель состоит из суммарного коэффициента рождаемости, смертности населения в трудоспособном возрасте, смертности от внешних причин, коэффициентов естественного и миграционного прироста населения региона; ожидаемой продолжительности жизни и заболеваемости населения по отдельным видам социально-значимых болезней;

2. Социально-экономический - уровень фактической безработицы, рассчитанной по методике Международной организации труда (МОТ), и процент населения с доходами ниже официально установленного прожиточного минимума в регионе.

3. Общественной безопасности - уровень преступности.

Рассмотрим показатели подробнее в таблице на примере Калмыкии, Бурятии и Тувы (все данные на конец 2017 г., за исключением конкретно указанных; среднее - по Южному (ЮФО) и Сибирскому (СФО) федеральным округам). Поскольку статистические данные приведены на 2017 г., соответственно Республика Бурятия учитывалась в составе СФО, ныне республика включена в состав Дальневосточного федерального округа. В таблице приведены два источника по доле населения с доходами ниже прожиточного минимума, поскольку данные несколько отличаются.

Таблица. Социально-экономические показатели Калмыкии, Бурятии и Тувы, по данным Росстата, на конец 2017 г.

Table. Social and economic indicators in Kalmykia, Buryatia and Tuva. Data by Rosstat, as of the end of 2017.

\begin{tabular}{|c|c|c|c|}
\hline Индикатор & Калмыкия & Бурятия & Тува \\
\hline $\begin{array}{c}\text { Численность населения региона в } \\
\text { конце 2010 г. (тыс. чел.) (Регионы } \\
\text { России ..., 2018: 39, 40) }\end{array}$ & 289 & 972 & 308 \\
\hline
\end{tabular}




\begin{tabular}{|c|c|c|c|}
\hline $\begin{array}{c}\text { Численность населения на } 1 \text { января } \\
2018 \text { г. (тыс. чел.) (Регионы России ..., } \\
\text { 2018: 18, 22) }\end{array}$ & 275,4 & 984,5 & 321,7 \\
\hline $\begin{array}{l}\text { Изменение численности населения } \\
\text { региона по сравнению с } 2010 \text { г., в \% }\end{array}$ & $(-) 4,7$ & (+) 1,2 & $(+) 4.4$ \\
\hline \multirow{2}{*}{$\begin{array}{c}\text { Коэффициенты естественного } \\
\text { прироста населения на } 1 \text { тыс. человек } \\
\text { населения } \\
\text { (Регионы России ..., 2018: 71-72) }\end{array}$} & \multirow{2}{*}{$\begin{array}{c}1,1 \\
\text { (в среднем } \\
\text { по ЮФО (-) } 1,8)\end{array}$} & 3,8 & 13,2 \\
\hline & & \multicolumn{2}{|c|}{ (в среднем по СФО (-) 0,4) } \\
\hline \multirow{2}{*}{$\begin{array}{c}\text { Суммарный коэффициент } \\
\text { рождаемости (число детей на } 1 \\
\text { женщину) } \\
\text { (Регионы России ..., 2018: 73-74) }\end{array}$} & \multirow{2}{*}{$\begin{array}{c}1,541 \\
\text { (в среднем } \\
\text { по ЮФО 1,586) }\end{array}$} & 2,056 & 3,194 \\
\hline & & \multicolumn{2}{|c|}{ (в среднем по СФО 1,720) } \\
\hline \multirow{2}{*}{$\begin{array}{c}\text { Коэффициенты миграционного } \\
\text { прироста на } 10 \text { тыс. человек населения } \\
\text { (Регионы России ..., 2018: 87-88) }\end{array}$} & \multirow{2}{*}{$\begin{array}{c}(-) 97 \\
\text { (в среднем } \\
\text { по ЮФО 27) }\end{array}$} & (-) 35 & (-) 33 \\
\hline & & \multicolumn{2}{|c|}{ (в среднем по СФО (-) 16) } \\
\hline $\begin{array}{c}\text { Ожидаемая продолжительность жизни } \\
\text { при рождении, лет (Регионы России ..., } \\
2018: 75-76)\end{array}$ & $\begin{array}{c}73,54 \\
(13 \text { место в РФ) }\end{array}$ & $\begin{array}{c}70,69 \\
(67 \text { место в РФ) }\end{array}$ & $\begin{array}{c}66,29 \\
(84 \text { место в РФ) }\end{array}$ \\
\hline \multirow{2}{*}{$\begin{array}{c}\text { Смертность населения в } \\
\text { трудоспособном возрасте } \\
\text { (число умерших на } 100 \text { тыс. человек } \\
\text { соответствующего возраста) (Регионы } \\
\text { России ..., 2018: 65-66) }\end{array}$} & \multirow{2}{*}{$\begin{array}{c}405,5 \\
\text { (в среднем } \\
\text { по ЮФО } 453,5)\end{array}$} & 546,2 & 729,1 \\
\hline & & \multicolumn{2}{|c|}{ (в среднем по СФО 583,9) } \\
\hline \multirow{2}{*}{$\begin{array}{c}\text { Смертность населения региона от } \\
\text { внешних причин смерти в } 2016 \text { г. } \\
\text { (число умерших на } 100 \text { тыс. человек } \\
\text { населения) (Приложение к сборнику } \\
\text { Здравоохранение в России 2017: } \\
\text { Электр. ресурс) }\end{array}$} & \multirow[t]{2}{*}{$\begin{array}{c}114,3 \\
\text { (в среднем } \\
\text { по ЮФО 95,7) }\end{array}$} & 164,7 & 261,8 \\
\hline & & \multicolumn{2}{|c|}{ (в среднем по СФО 141,8) } \\
\hline \multirow{2}{*}{$\begin{array}{c}\text { Контингент пациентов с алкоголизмом } \\
\text { и алкогольными психозами } \\
\text { (численность пациентов, состоящих } \\
\text { на учете в лечебно-профилактических } \\
\text { организациях на конец } 2016 \text { г. на } 100 \\
\text { тыс. чел. населения) (Приложение к } \\
\text { сборнику Здравоохранение в России } \\
2017: \text { Электр. ресурс) }\end{array}$} & \multirow[t]{2}{*}{$\begin{array}{c}941,3 \\
\text { (в среднем } \\
\text { ЮФО 832) }\end{array}$} & 728,8 & 1175 \\
\hline & & \multicolumn{2}{|c|}{ (в среднем по СФО 862,3) } \\
\hline
\end{tabular}




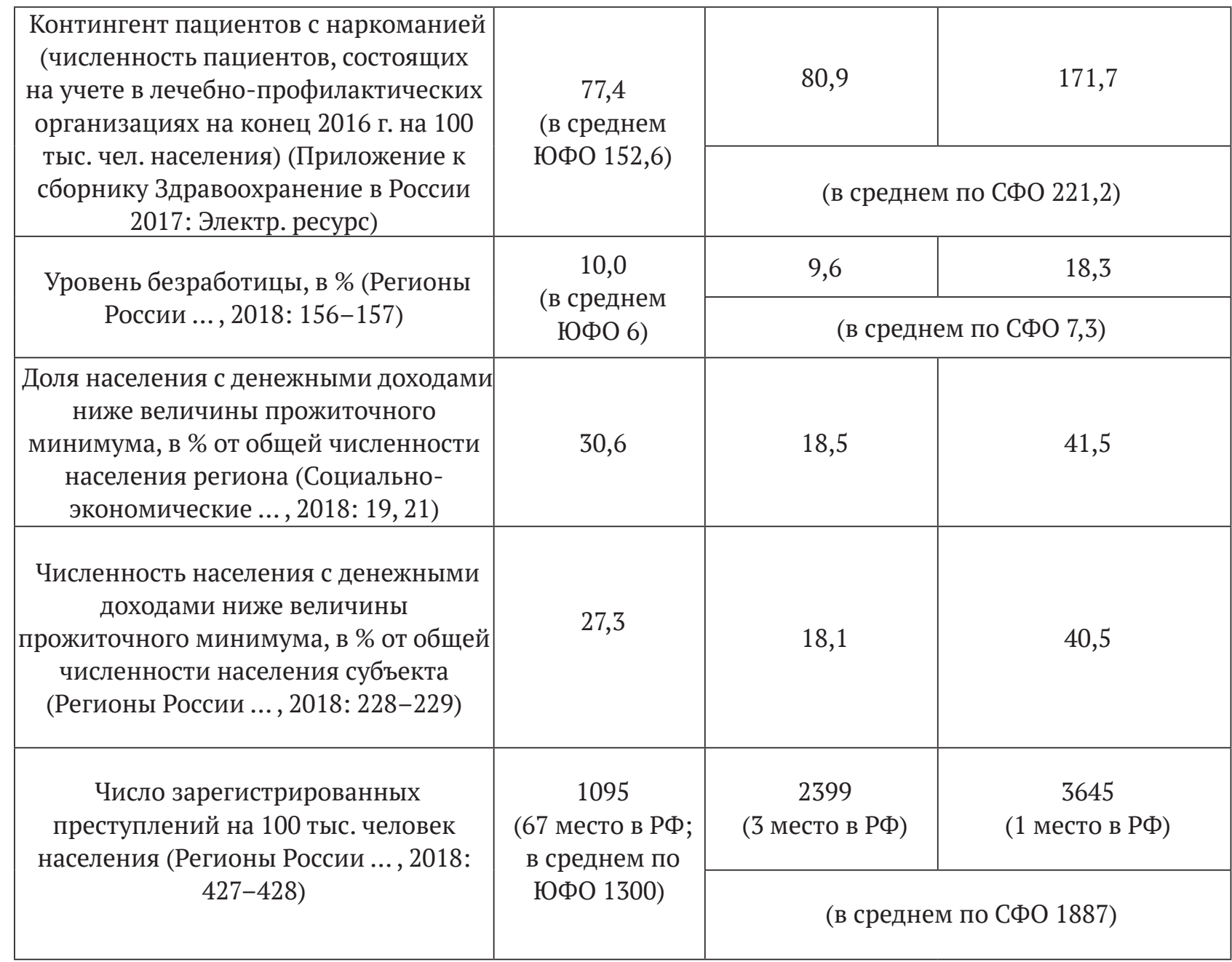

Согласно статистическим данным, Калмыкия и Тува по численности населения находятся в одной «весовой категории», однако тенденции демографического развития разнятся. В первую очередь, население Республики Калмыкия продолжает сокращаться, прежде всего, вследствие миграционного оттока, тогда как население Тувы увеличивается благодаря естественному приросту, обусловленного высокой рождаемостью.

Тува занимает одно из первых мест в Российской Федерации по показателям рождаемости. Среди факторов, способствующих сохранению традиций многодетности, исследователи называют, в частности, проживание коренного населения в сельской местности, слабую миграционную подвижность, которую связывают с проблемой языкового барьера, навыками к определенным условиям труда и быта, привязанностью к родительскому дому и родным местам, тесными родственными связями (Севек В., Соян, Севек Р., 2016: 143).

Вместе с тем, отмечается, что демографическая ситуация, сложившаяся в Туве, вызывает серьезное беспокойство: налицо все признаки демографического кризиса. Численность населения Тувы за последние 17 лет (с 2000 до 2016 г.) увеличилась на 9,4 тыс. человек или на $3,1 \%$ (в среднем - на 0,63 тыс. чел. или на 0,2\% в год). Наличие высокого уровня рождаемости в Туве недостаточно для обеспечения воспроизводства населения, поскольку ожидаемая при рождении продолжительность жизни в Туве в среднем на 9 лет ниже, чем по России в целом.

Общая положительная динамика численности не может считаться благополучной, поскольку республика отличается высоким уровнем смертности населения трудоспособного возраста, что обусловлено высоким уровнем заболеваемости населения, распространенностью алкоголизма, наркомании, курения. Как пишет Ш. Ч. Соян, «в республике не созданы условия, побуждающие 
людей бережно относиться к своему здоровью и здоровью своих детей. Недостаточно развита организация форм досуга, способствующих здоровому образу жизни, таких как физическая культура, спорт, туризм, активный отдых и др. Все нарастающая урбанизация, увеличение доли городского населения, отток сельских жителей в Кызыл - все это ведет к значительной дифференциации территории республики по плотности населения» (Соян, 2016: 102-103).

Согласно социологическим данным, «Тува не является регионом, привлекательным для работы и проживания значительного количества молодых жителей, у них достаточно выражены миграционные установки на отъезд из региона. Молодежь выражает желание уехать, чтобы получить высшее образование за пределами Тувы, найти работу» (Севек В., Соян, Севек Р., 2016: 143).

Представляется, что отток молодого поколения из Тувы за пределы региона, прежде всего в силу причин трудовой миграции, в перспективе может сказаться на социально-экономическом благополучии региона, сдерживать его развитие.

Как полагает Д. Ф. Дабиев, многие проблемы в Туве имеют не только экономические причины, но и связаны более глубинными факторами, прежде всего «ломкой духовных ценностей и традиционного образа жизни тувинцев, который произошел в процессе перехода с кочевого образа жизни на оседлый. Последствия этих масштабных реформ катастрофичны: рост преступности и смертности населения наблюдается с советских времен, и рыночные преобразования лишь усугубили ситуацию» (Дабиев, 2015: 183).

Однако, на наш взгляд, что подтверждают статистические данные, указанные выше и региональные исследования, в Туве социальное неблагополучие проявляется, прежде всего, как следствие экономической ситуации. Безработица, низкий уровень доходов опосредуют и остальные негативные явления в социально-демографических показателях и в общественной безопасности. Во всех трех рассматриваемых регионах, как и в целом по России, особую остроту составляет хроническая безработица в сельской местности. Упадок сельскохозяйственного производства приводит к оттоку сельского населения в города, или за пределы региона, однако, в Туве ситуация осложняется, как представляется, также в силу ее географического периферийного положения, неразвитости транспортной инфраструктуры, что затрудняет мобильность населения.

Бурятия в этом ряду стоит обособленно. Численность региона приближается к миллиону человек, в республике, как отмечает И. И. Осинский, также «зафиксирован один из самых высоких в СФО и России суммарный коэффициент рождаемости. В 2016 г. он равнялся 2,237. Темп прироста данного показателя, по сравнению с 2006 г., составил 31,8\% и вплотную приблизился к соответствующему общероссийскому показателю, который в 2016 г. равнялся 34,8\%» (Осинский, 2017: 146).

Однако, для Бурятии также характерны проблемы смертности трудоспособного населения, а также миграционный отток из республики. Основными причинами миграционных настроений И. И. Осинский называет: низкую заработную плату, высокий уровень бедности, безработицу, узкий внутренний республиканский рынок с низкооплачиваемыми вакансиями и социально непрестижными рабочими местами, ограниченными возможностями для реализации молодых специалистов. Эти же причины, считает он, в основном детерминируют и внутреннюю миграцию, которую исследователь называет преобладающей (Осинский, 2017: 154).

По мнению А. В Бильтриковой, относительное благополучие в уровне жизни граждан Бурятии по сравнению с соседними регионами, представляемое статистическими данными, не дает полной картины происходящей депривации населения. «Реальная оценка уровня бедности и уровня дифференциации доходов населения остается проблематичной», - пишет она (Бильтрикова, 2016: 132).

Калмыкия и Тува схожи по показателям уровня безработицы и доле населения с доходами ниже прожиточного минимума в населении региона. По данным критериям обе республики относятся к числу беднейших субъектов Российской Федерации. 
По результатам социологического опроса населения Калмыкии «Проблемы социального неравенства и социальной дифференциации в Республике Калмыкия» (N=500), проведенного отделом социально-политических и экологических исследований Калмыцкого института гуманитарных исследований РАН в 2015 г. (руководитель опроса Н. В. Бадмаева) наибольшие показатели о причинах бедности набрали ответы респондентов: длительная безработица $(23,3 \%)$ и проживание в бедном регионе (20,2\%), низкие зарплаты (17,8\%) (Бадмаева, $2017: 16)$. Географическое расположение в европейской части страны, транспортная доступность способствуют массовой трудовой миграции населения Калмыкии в мегаполисы - города Москву и Санкт-Петербург, где практически нет проблем с занятостью населения и высокие зарплаты. По тем же причинам часть трудовых мигрантов из Калмыкии выбирает регионы Крайнего Севера и Дальнего Востока Российской Федерации.

В 2017 г. отделом комплексного мониторинга и информационных технологий Калмыцкого научного центра Российской академии наук было проведено исследование, посвященное проблемам занятости и миграции сельского населения Республики Калмыкия ( $=500)$ (руководитель опроса Н. В. Бадмаева).

В качестве контрольной группы выступили жители г. Элисты - 200 респондентов, соответственно сельское население составило 300 респондентов. В целом исследование показало, что 24,3\% респондентов готовы выехать на работу за пределы республики, при этом 9,6\% респондентов отметили, что покинут республику, если ухудшится их материальное положение. Следует отметить, что сельские жители в большей степени нацелены на миграцию: 40\% респондентов готовы выехать на работу за пределы республики. Экономические причины миграции назвали 70,4\% респондентов, среди них преобладают следующие ответы - недостаточный уровень материального обеспечения и улучшение жилищных условий (Бадмаева, 2018: 25).

Массовая трудовая миграция за пределы региона ставит под угрозу социально-экономическую безопасность Калмыкии, ведет к депопуляции республики, что может отрицательно сказаться и на демографических перспективах калмыцкого этноса. Из региона уезжают, в том числе квалифицированные кадры, что порождает соответствующий «дефицит» специалистов даже в тех секторах экономики республики, где имеются рабочие места и вакансии.

\section{Заключение}

Сложное социально-экономическое положение регионов, вызванное в том числе и кризисностью сельскохозяйственной отрасли, которая является в большей степени основой экономики Калмыкии, Тувы и Бурятии, по нашему мнению, в значительной степени влияет на проявление показателей социального неблагополучия в регионах. Однако, несмотря на внешнюю схожесть социальных и экономических проблем Калмыкии, Бурятии и Тувы, последствия социального неблагополучия каждого из регионов видятся по-разному. Массовая трудовая миграция населения за пределы Калмыкии «вымывает» этническую составляющую республики, фактически ставя под угрозу существование малочисленного народа как отдельной этнической общности в долгосрочной перспективе в связи с рассеянием и вынужденной ассимиляцией.

В Бурятии относительно стабильная ситуация, так как регион более развит в социальноэкономическом отношении. Вместе с тем, большинство показателей нельзя назвать благоприятными (уровень безработицы, преступности и др.).

Социальная ситуация в Туве, как представляется, противоречива. С одной стороны, благодаря высокому уровню рождаемости и естественного прироста тувинское общество противостоит негативным процессам депопуляции в виде высокого уровня смертности, низкой ожидаемой продолжительности жизни и миграционного оттока из региона. С другой, бедность населения, безработица провоцируют общее социальное неблагополучие общества, которое сказывается на демографических, социально-экономических показателях, а также общественной безопасности. 


\section{СПИСОК ЛИТЕРАТУРЫ}

Бадмаева, Н. В. (2017) Проблема социального неравенства и бедности в регионе (на примере Республики Калмыкия) // Всероссийский форум молодых ученых: сборник материалов (Екатеринбург, 27-28 апреля 2017 г.). Екатеринбург : Уральский федеральный университет им. первого Президента России Б.Н. Ельцина. 285 с. С. 13-18.

Бадмаева, Н. В. (2018) Проблемы безработицы и миграционные настроения сельского населения Калмыкии (по результатам социологического исследования) // Бюллетень Калмыцкого научного центра РАН. Выпуск 2. С. 23-28.

Бильтрикова, А. В. (2016) Показатели бедности в России и Бурятии // Улан-Удэ - 350 лет: история, пространство, общество : сб. науч. ст. / отв. ред. Б. В. Базаров. Иркутск : Изд-во «Оттиск». 563 с. С. $128-133$.

Дабиев, Д. Ф. (2015) Человеческий капитал и индекс преступности (на примере Тывы) // ЭКО. № 2 (488). С. 176-183.

Давыдов, А. А. (1995) Индекс социального неблагополучия // Социологические исследования. № 10. С. 118-128.

Кандрычын, С. В. (2017) Смертность от внешних причин и социокультурная дифференциация российских регионов // Проблемы развития территории. № 3 (89). С. 78-91.

Ламажаа, Ч. К. (2009) Социальная архаизация постсоветской Тувы // Знание. Понимание. Умение. № 2. С. 124-129.

Мартынова, Ю. Ю., Блинова, С. В. (2016) Анализ преступности по регионам Российской Федерации // Приложение математики в экономических и технических исследованиях. № 1 (6). С. 99-110.

Осинский, И. И. (2017) Демографическое развитие Бурятии // Вестник Института социологии. Т. 8. № 4 (23). С. 138-158.

Печкова, О. В. (1996) Что показывает индекс социального неблагополучия // Социологические исследования. № 1. С. 155-156.

Приложение к сборнику Здравоохранение в России 2017 (2018) [Электронный ресурс] // Росстат. URL: http://www.gks.ru/free_doc/doc_2017/pril_zdravo.rar (дата обращения 25.12.2018).

Регионы России. Социально-экономические показатели. 2018 (2018): статистический сборник. М. : Росстат. 1162 с.

Севек, В. К., Соян, Ш. Ч., Севек, Р. М. (2016) Социальное самочувствие молодежи Республики Тыва // Социологические исследования. № 9. С. 141-144.

Социально-экономические индикаторы бедности в 2013-2017 гг. (2018) [Электронный ресурс]// Росстат. URL: http://www.gks.ru/bgd/regl/b18_110/Main.htm (дата обращения 25.12.2018)

Соян, Ш. Ч. (2016) Современная демографическая ситуация в Туве // География Тувы: образование и наука. Материалы Республиканской научно-практической конференции к 85-летию первого учёного-географа Тувы К. О. Шактаржика / (27.10.2016, Кызыл, Россия) / отв. ред. В. И. Лебедев. Кызыл : ТувИКОПР СО РАН. 148 с. С. 101-104.

Тихомирова, Т. М., Сукиасян, А. Г. (2018) Влияние факторов социального неблагополучия на оценку человеческого потенциала в регионах России // Федерализм. № 2 (90). С. 64-78.

Дата поступления: 14.01.2019 2.

\section{REFERENCES}

Badmaeva, N. V. (2017) Problema sotsial'nogo neravenstva i bednosti v regione (na primere Respubliki Kalmykiia) [The problem of social inequality and poverty in the region: the case of the Republic of Kalmykia)]. In: Vserossiiskii forum molodykh uchenykh [All-Russian forum of young scientists]: a collection of papers. (Ekaterinburg, 27-28 aprelia 2017 g.). Ekaterinburg, Ural'skii federal'nyi universitet im. pervogo Prezidenta Rossii B. N. El'tsina. 285 p. Pp. 13-18. (In Russ.). 
Badmaeva, N. V. (2018) Problemy bezrabotitsy i migratsionnye nastroenia sel'skogo naselenia Kalmykii (po rezul'tatam sotsiologicheskogo issledovania) [Problems of unemployment and migration attitudes of the rural population of Kalmykia: the results of a sociological study)]. Bulletin of the Kalmyk Scientific Center of the Russian Academy of Sciences, issue 2, pp. 23-28. (In Russ.).

Bil'trikova, A. V. (2016) Pokazateli bednosti v Rossii i Buriatii [Poverty indicators in Russia and Buryatia]. In: Ulan-Ude - 350 let: istoriia, prostranstvo, obshchestvo [350 years of Ulan Ude: history, space, society]. A collection of articles / ed. by B. V. Bazarov. Irkutsk, Ottisk Publ. 563 p. Pp. 128-133. (In Russ.).

Borodkin, F. M. (2004) Sotsial'nye indikatory - chto eto takoe? [Social indicators - what are they?]. Universe of Russia, no. 4, pp. 62-101. (In Russ.).

Dabiev, D. F. (2015) Chelovecheskii kapital i indeks prestupnosti (na primere Tyvy) [The human capital and the index of crime: the case of Tuva]. ECO, no. 2 (488), pp. 176-183. (In Russ.).

Davydov, A. A. (1995) Indeks sotsial'nogo neblagopoluchiia [Index of social insecurity]. Sotsiologicheskie issledovaniia, no. 10. pp. 118-128. (In Russ.).

Kandrychyn, S. V. (2017) Smertnost' ot vneshnikh prichin i sotsiokul'turnaia differentsiatsiia rossiiskikh regionov [Mortality from external causes and socio-cultural differentiation of the Russian regions]. Problems of Territory's Development, no. 3 (89), pp. 78-91. (In Russ.).

Lamazhaa, C. K. (2009) Socialnaya arhaizatsia postsovetskoi Tuvy [Social archaization of postSoviet Tuva]. Znanie. Ponimanie. Umenie, no. 2. pp. 124-129. (In Russ.).

Martynova, Iu. Iu. and Blinova, S. V. (2016) Analiz prestupnosti po regionam Rossiiskoi Federatsii [An analysis of crime across the regions of the Russian Federation]. Prilozhenie matematiki $v$ ekonomicheskikh i tekhnicheskikh issledovaniiakh, no. 1 (6), pp. 99-110. (In Russ.).

Osinskii, I. I. (2017) Demograficheskoe razvitie Buriatii [Demographic development of the Republic of Buryatia]. Vestnik Instituta sotsiologii, vol. 8, no. 4 (23), pp. 138-158. (In Russ.).

Pechkova, O. V. (1996) Chto pokazyvaet indeks sotsial'nogo neblagopoluchiia [What the index of social insecurity reveals]. Sotsiologicheskie issledovaniia, no. 1, pp. 155-156. (In Russ.).

Prilozhenie k sborniku Zdravookhranenie v Rossii 2017 (2018) [The annex to the collection Healthcare in Russia, 2017]. Rosstat [online] Available at: URL: http://www.gks.ru/free_doc/ doc_2017/pril_zdravo.rar (access data: 25.12.2018). (In Russ.).

Regiony Rossii. Sotsial'no-ekonomicheskie pokazateli. 2018 [Regions of Russia: Social and economic indicators: a statistical compendium. 2018] (2018). Moscow, Rosstat. 1162 p. (In Russ.)

Sevek, V. K., Soian, Sh. Ch. and Sevek, R. M. (2016) Sotsial'noe samochuvstvie molodezhi Respubliki Tyva [Social well-being of youth in the Republic of Tuva]. Sotsiologicheskie issledovaniia, no. 9, pp. 141-144. (In Russ.).

Sotsial'no-ekonomicheskie indikatory bednosti v 2013-2017 gg. [Social and economic indicators of poverty, 2013-2017] (2018) / Federal'naia sluzhba gosudarstvennoi statistiki (Rosstat). Moscow, Rosstat. (In Russ.).

Soian, Sh. Ch. (2016) Sovremennaia demograficheskaia situatsiia v Tuve [Contemporary demographic situation in Tuva]. In: Geografiia Tuvy: obrazovanie i nauka [Geography of Tuva: education and science]. Materials of a regional research conference devoted to 85th birthday of the first geographer of Tuva, K. O. Shaktarzhik] / (27.10.2016, Kyzyl, Rossiia) / ed. by V. I. Lebedev. Kyzyl, TuvIKOPR SO RAN. 148 p. Pp. 101-104. (In Russ.).

Tikhomirova, T. M. and Sukiasian, A. G. (2018) Vliianie faktorov sotsial'nogo neblagopoluchiia na otsenku chelovecheskogo potentsiala $\mathrm{v}$ regionakh Rossii [Influence of social insecurity on assessments of human potential in the regions of Russia]. Federalizm, no. 2 (90), pp. 64-78. (In Russ.). 